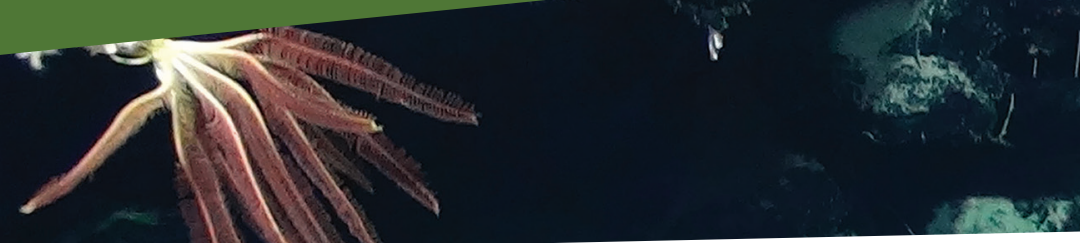

.

\title{
MARINE GEOSCIENCE: JUST A DROP IN THE OCEAN
}

PROFESSOR BRAM MURTON IS THE ASSOCIATE HEAD OF MARINE GEOSCIENCE AT THE NATIONAL OCEANOGRAPHY CENTRE. IN THE UK. HIS RESEARCH COVERS MANY AREAS, INCLUDING THE DEEP OCEAN MINING OF MATERIALS SUCH AS TELLURIUM, WHICH CAN BE USED TO PRODUCE RENEWABLE ENERGY TECHNOLOGIES

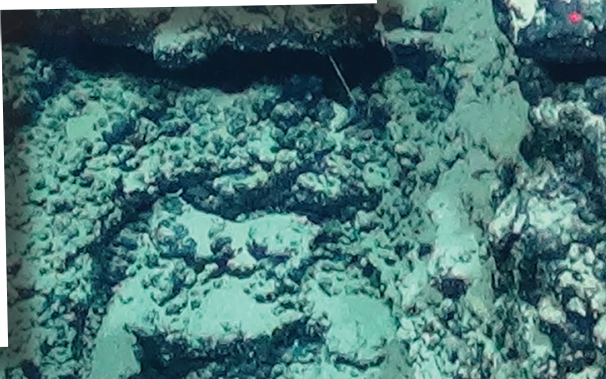

\section{IMAGIN THIS}

You don't have to go into space to be the first human being ever to explore an area: $70 \%$ of our planet is covered by water and yet only $2 \%$ has been explored.

With the help of submarine robots, Bram and his team are finding new ways to mine for minerals and metals under the sea. These materials can be used to build solar panels, rechargeable batteries (for electric cars) and magnets needed for wind turbines.

Could deep sea mining be the solution we need to reduce mankind's reliance on carbon-based fossil fuels?
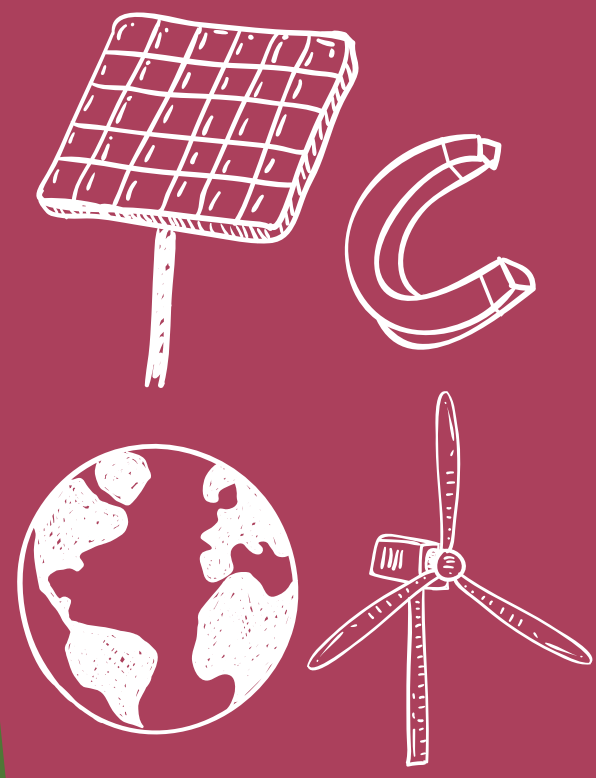

Our planet is an extremely vast place with an apparent abundance of riches. However, as the global population continues to grow rapidly, the demand for materials is outstripping our ability to recycle existing sources and replace what has been used. In addition, the burning of carbon-based fossil fuels has damaged Earth and significantly contributed to global warming and climate change. For these reasons, it is important for us to find new minerals and metals, particularly those that are essential to building low-carbon technologies.

One exciting, and surprisingly underutilised, potential source of new minerals and metals is the seas and oceans. Seventy percent of the Earth's surface is covered by water and the deep seafloor contains mineral deposits in the form of manganese and iron-rich nodules, cobalt-rich crusts and massive sulphides.

It is these cobalt-rich crusts that are the focus of Professor Bram Murton's research. As the Associate Head of Marine Geoscience at the National Oceanography Centre, in the UK. Bram leads a team of scientists who are interested in cobalt, tellurium and rare earth elements.

\section{WHAT ARE THESE}

\section{ELEMENTS USED FOR?}

Cobalt is used in many materials, from special alloys in aircraft to machine tools, and more recently in rechargeable batteries. At the moment, $70 \%$ (90,000 tonnes per year) of cobalt comes from the Democratic Republic of Congo, a war-torn country in central Africa. Cobalt is not mined directly but is a by-product of copper production. In the future, demand for cobalt will be driven by electric cars.

Tellurium is a very rare element, even rarer than gold. Its traditional uses are for leadacid batteries, as a pigment in ceramics (needed to create beautiful colours), and as a catalyst in hydrocarbon refining (an industrial process where crude oil is transformed into useful products such as petrol). Bram's

interest in tellurium is in its use for improving the efficiency of solar panels to convert sunlight into electricity.

There are 15 rare earth elements listed in the lathanide series (a group of elements in the periodic table) and, in spite of their group name, are not particularly rare especially when compared with tellurium. But they have special properties that make them in high demand. For example, the heavy rare earth elements neodynium and praseodymium are used in strong electric magnets that are essential for electric motors and wind turbines. Rare earth elements are also used as catalysts in chemical reactions, in mobile phones and computer memory.

HOW AND WHY DO RESEARCHERS MINE UNDER THE SEA?

The grade of the metals is higher for many elements in seafloor minerals than on land. That means less rock has to be removed to get the same amount of metal. Then there is the fact that seafloor mines do not need infrastructure like roads, railways, or the relocation of people from their homes. 
Marine geoscience is a form of planetary science which involves studying the Earth. Seventy percent of our planet is covered by ocean and, similar to space exploration, there is so much that we still do not understand. Marine geoscientists aim to fill in these knowledge gaps using a wide range of tools and methods. Both robotic and manned vehicles are used to explore the deep-ocean floor down to 6,500 metres below the sea surface. It is possible to explore even deeper - down to 11,000 metres - the deepest places on Earth!

WHAT IS IT LIKE TO BE A

GEOSCIENTIST?

Being a marine geoscientist is extremely exciting as you have to be an expert in lots of different areas: technology (sometimes designing your own vehicles and machines), geology (to understand the formation of the rocks and minerals), geophysics (to understand the remote sensed data and sonars), geochemistry (to analyse the rocks in the lab), a mariner that is happy to go to sea on expeditions for weeks at a time, and an enthusiast for the unknown (only $2 \%$ of the world's oceans have been explored - so wherever you go, you are nearly always the first human being to see it and explore it).

WHAT CAREER OPPORTUNITIES ARE AVAILABLE WITH A DEGREE IN MARINE GEOSCIENCE?

Careers in marine geoscience research are hard to get, but far from impossible. If you follow your dreams and have a little bit of luck, then a career in this field could be within your grasp. Other related career opportunities are on the rise: offshore surveying is growing fast with the drive for renewable energy from offshore wind and wave, or oil and gas - and this requires marine geophysicists; marine-protected areas require surveyors to monitor for changes; cables cross the oceans and require marine geoscientists to survey where to lay them; and in the near future, deep-sea mining will require deep-sea mineral exploration.

WHY SHOULD YOUNG PEOPLE WANT TO STUDY MARINE GEOSCIENCE?

For many reasons! Geoscience is an adventure and has the power to make a huge difference to people and mankind - from understanding the history of climate change, to providing resources and materials from which we can build a sustainable future civilisation. It is varied, and never boring.

\section{OPPORTUNITIES IN GEOSCIFNGE}

- The British Geological Survey has an entire area of its website dedicated to training within the field of geoscience: www.bgs.ac.uk/training/home.html

- The Geological Society says that a starting salary for a geoscientist can vary anywhere between $£ 28,000$ and $£ 35,000$, with senior geoscientists earning between $£ 40,000$ and $£ 75,000$ per year

- The Geological Society has also created a wonderful Geology Career pathways webpage, which allows you to explore your career pathway by clicking on animated characters. Have a go and see where a geology career could take you! www.geolsoc.org.uk/Geology-Career-Pathways

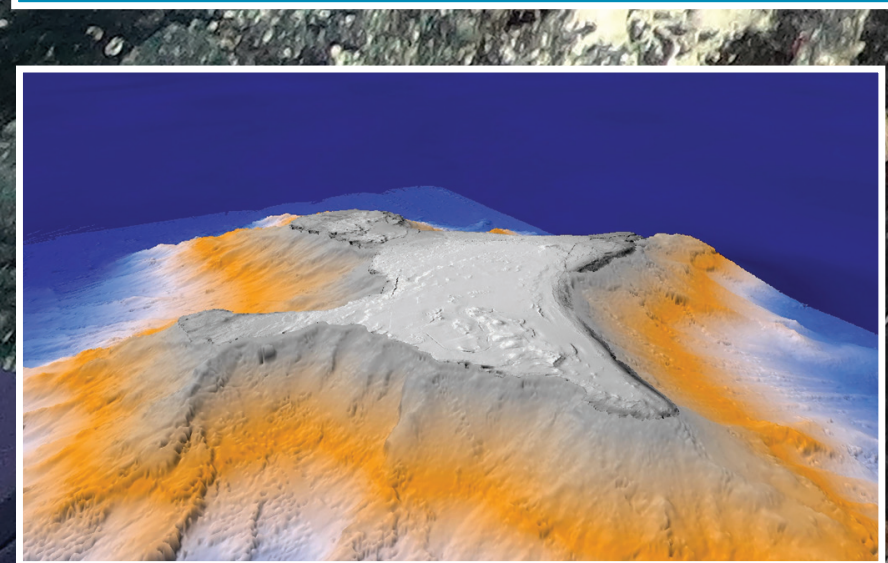

Multibeam sonars from the surface ship and deep-diving robotic submarines map the shape of Tropic Seamount, which is $40 \mathrm{~km}$ wide and between 1 and $4 \mathrm{~km}$ deep.
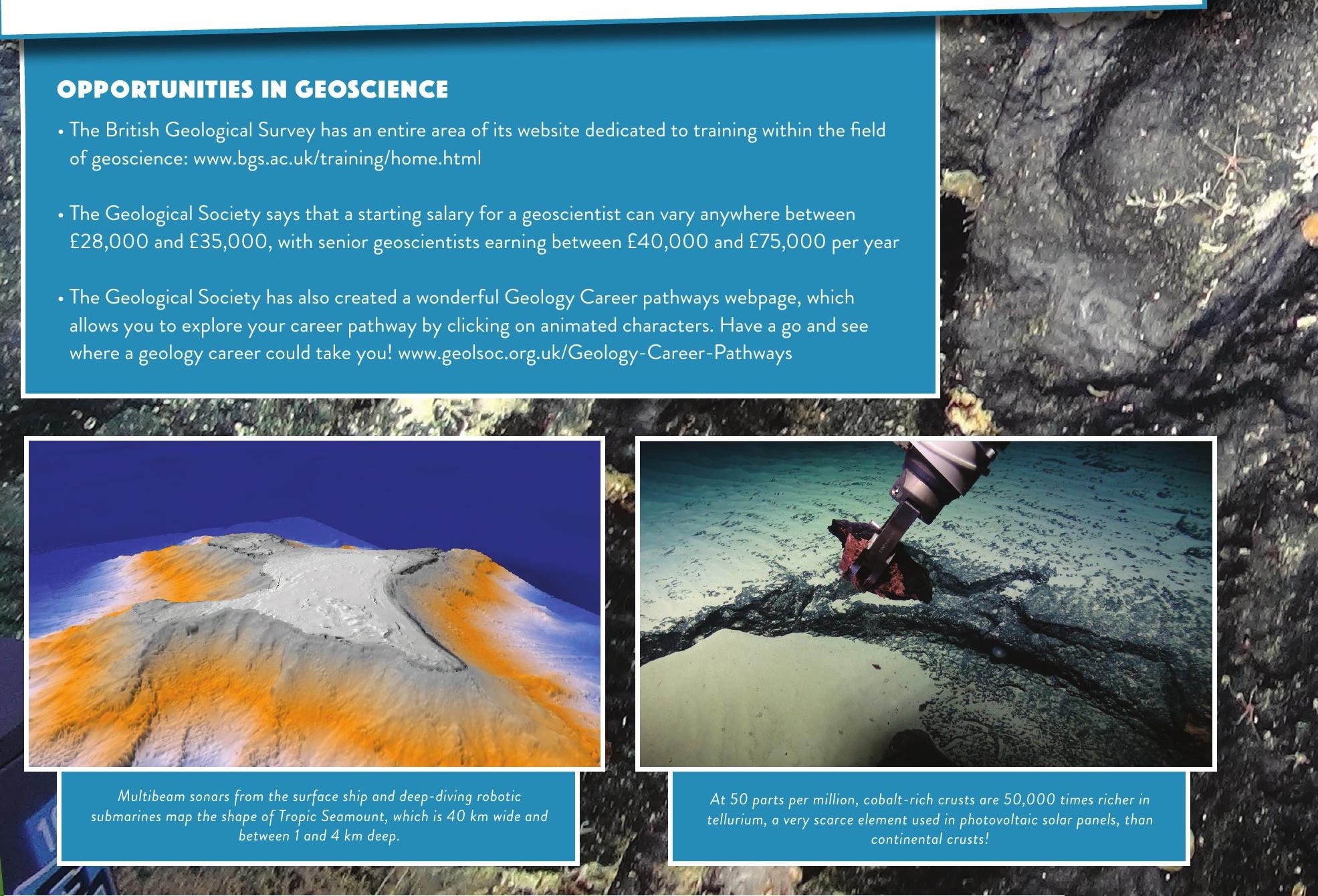

At 50 parts per million, cobalt-rich crusts are 50,000 times richer in tellurium, a very scarce element used in photovoltaic solar panels, than 
WHAT DID YOU WANT TO BE WHEN YOU WERE GROWING UP?

I was interested in everything technical, scientific and to do with space. We lived in the west coast of Scotland and I remember trying to build an underwater lab from an old large metal water tank. Luckily it floated away! My heroes were the Tomorrow's World presenters. However, it would be untrue to say that I dreamt of being a scientist or that I plotted a path to be a professor at an early age. I followed my curiosity and developed my interests in our natural world, and the rest came from serendipity and blind enthusiasm.

\section{WHAT MADE YOU WANT TO} STUDY GEOLOGY AND MARINE GEOSCIENCES?

As a kid, I was once taken on a goldpanning trip by a famous Antarctic explorer and geologist who was on holiday in my village. I asked lots of questions about the mountains, the minerals we could see, and how the Earth formed. The answers were fascinating, and I longed to understand how an apparently unique planet like the Earth was formed. After tossing a coin to choose between studying geology and geophysics at Edinburgh University (geology won), I went on to do a PhD at the Open University under the supervision of Professor lan Gass FRS, researching the Troodos Ophiolite - an uplifted fragment of 90 million year-old oceanic crust that now forms the mountains of Cyprus.

Fascinating as this was, I became increasingly aware that the $70 \%$ of Earth covered by the ocean is almost unknown, and I wanted to find out more about plate tectonics in action. I was invited on an oceanographic research cruise mapping the seafloor in the West Pacific with new sonar systems. Being the first to see the seafloor in this region, and the first to see new volcanoes and faults, got me hooked.

YOUR RESEARCH FOCUSES ON FINDING MATERIALS THAT ARE USED MAINLY FOR LOW CARBON AND RENEWABLE ENERGY TECHNOLOGIES (SOLAR PHOTOVOLTAIC, WIND TURBINES AND ELECTRIC VEHICLES). ARE YOU AN ECO-WARRIOR?

I am not a warrior of any kind - except maybe for the rational truth. But I am deeply concerned about the planet; it's our only one and will always be unique for us. I am concerned that people are consuming it without regard for the future. I want people to have a happy and healthy life, without destroying everything around us. This leads us to a dilemma: to become more sustainable, people must recycle and use more renewable energy, but there aren't enough of those materials to make this happen. So, we need more raw materials. This sounds contradictory, to reduce consumption we need to consume more, but it is about consuming the right sort of materials that ultimately enable us to consume less. Deep-sea mining has a lot of potential advantages over land-based mining. To realise the full potential, we need to find out a lot more about the nature of the mineral deposits, where they form and are most concentrated, and the effects of mining them. I am motivated by helping people to have a sustainable future, reducing poverty and preserving our planet.

\section{FINALLY, WHAT DO YOU LOVE MOST} ABOUT YOUR JOB?

My job has given me the opportunity to discover things, to explore places and to see things no one has ever seen before. Its variety and opportunity have been amazing. I have built machines that have discovered the deepest and hottest hydrothermal vents on Earth. I have dived in a mini-submarine 3,500 metres below the surface to discover new forms of life. I have built teams and made new friends around the world, from multiple different cultures, all enthusiastic about discovery. My work, I hope, will ultimately help solve some of the world's problems. I have been given the chance to make a difference for the better.

\section{BRAMS TOP TIPS FOR STUDENTS}

01 One of the most important things is to remember that scientists are just like everybody else. It is perfectly normal to be enthusiastic, interested, questioning and unsure of one's self. Keep this in mind at all times.

Marine geoscience requires a wide range of skills. A grounding in chemistry and physics at $A$ level is a good start. Plus, a wider range of skills including team work, independent and critical thinking, self-reliability and sociability are essential.

If you get the chance, meet people in the business, go to trade shows and talk with people from the industry and local geological society - and attend talks! They are often by experts in the field and can be inspiring.

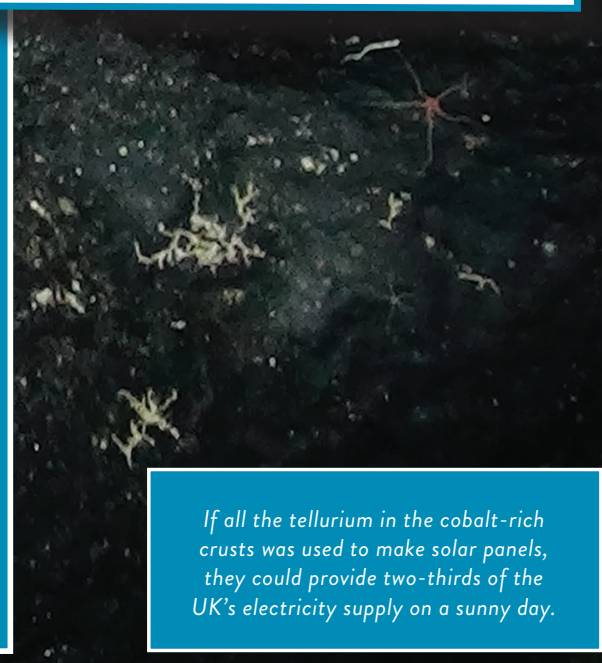

